\title{
SYNTHESIS, CHARACTERIZATION, THERMAL PROPERTIES AND ANTIMICROBIAL ACTIVITY OF ACRYLIC COPOLYMERS DERIVED FROM 2,4-DICHLOROPHENYL ACRYLATE
}

\author{
ANKIT K. PATEL, RAJESH J. PATEL, KIRIT H. PATEL AND RAJNI M. PATEL \\ Department of Chemistry, Sardar Patel University, Vallabh Vidyanagar-388120, Gujarat, India \\ (Received: September 2, 2008 - Accepted: October 28, 2008)
}

\begin{abstract}
Copolymer of monomer 2,4-dichlorophenylacrylate (2,4-DCPA) and methylmethacrylate (MMA) were synthesized with different monomer feed ratio using dimethylformamide (DMF) as a solvent and 2,2'-azobisisobutyronitrile (AIBN) as an initiator at $70^{\circ} \mathrm{C}$. The copolymers were characterized by IR-Spectroscopy and copolymer composition was determined with UV-Spectroscopy. The linearization method of Fineman Ross (F-R) and Kelen Tudos (K-T) were used to obtain the monomer reactivity ratios. Thermal analyses of polymer were carried out in nitrogen atmosphere thermal gravimetric analyses (TGA) and differential thermal analyses (DTA). The molecular weight and intrinsic viscosity were determined by vapor pressure osmometry (VPO). The homo and copolymers were tested for their antimicrobial properties against selected microorganisms.
\end{abstract}

Key words: Copolymer / Thermal Analysis / Reactivity Ratio / Antimicrobial Activity

\section{INTRODUCTION}

Copolymer is the most successful and powerful method for effecting systematic change in polymer [1]. Phenyl acrylate polymers are relatively newly developed materials compared to the commercial polymer such as vinylics. Acrylate is considered as reactive monomers primarily because of the presence of aromatic ring [2]. Choudhary Veena and coworkers [3-5] prepared copolymer of methyl methacrylate (MMA) with a variety of vinyl monomers. Strum [6] reported about thirty eight ester useful as commercial bactericides and fungicides. Plunder and coworkers [7] synthesized acrylics ester, useful as biocides by reacting pentachloro phenol, $p$-chloro- $m$-cresol, $o$-phenyl phenol with acryloyl chlorides. Patel and coworkers $[8,9]$ prepared copolymer from 2,4-diclorophenyl methacrylate with various vinyl monomers and reported that these polymer are useful as micro biocides are thermally stable up to $250^{\circ} \mathrm{C}$. Ibrahim Erol $[10,11]$ prepared new methacrylate monomer and their derivatives and copolymerized these monomers with various vinyl monomers. Bozkurt and Karadedeli [12] prepared copolymers of 4(5)-vinylimidazole and ethylene glycol methacrylate phosphate. Vijayanand and coworkers [13] prepared novel methacrylic monomer, 4-nitro-3-methylphenyl methacrylate (NMPM) by reacting 4-nitro-3-methylphenol with methyacryloyl chloride in the presence of triethylamine as catalyst. Senthilkumar and coworkers $[14,15]$ prepared new methacrylate monomer and copolymerized it with different feed ratio of styrene/ methyl acrylate/ $N$-vinyl pyrrolidone. Reactivity ratio was calculated by applying conventional linearization method of F-R and K-T. These authors tested biological activity of polymers and reported that these polymers show good biological activity.

The present work deals with the synthesis and characterization of monomer, homopolymer and copolymers. The copolymer composition was determined by UV spectroscopy. Reactivity ratios were determined using F-R and K-T methods. The molecular weight and intrinsic viscosity were determined by VPO. Thermal stability of the polymers was also studied. Biological activity of the homo and copolymers were carried out against selected microorganism like bacteria, fungi and yeast.

\section{EXPREMENTAL}

\section{Materials:}

Acrylic acid (Chiti chem. Baroda), Benzoyl chloride (Chiti chem. Baroda), Hydroquinone (S.D. fine chem.), 2,2'-azobisisobutyronitrile (AIBN, Aldrich), 2,4-diclorophenol (S.D. fine chem.), were analytical grade reagent (i.e. $98 \%$ pure) and used without further purification. Fractionally distillation solvent was used in the reactions.

\section{Synthesis of Acryloyl chloride}

Acryloyl chloride was prepared according to the process reported in the literature [16].

\section{Synthesis of 2,4-dichlorophenyl acrylate (2,4-DCPA).}

To a one liter three necked flask equipped with stirrer, thermometer and guard tube, absolute alcohol $(200 \mathrm{~mL})$ and $\mathrm{NaOH}(0.1$ mole $)$ were added and the contents were stirred until all the $\mathrm{NaOH}$ dissolved. To this, 2,4-dichloro phenol $\left(0.1\right.$ mole) was added. The reaction mixture was heated at $60{ }^{\circ} \mathrm{C}$ for 30 minutes with stirring, cooled to room temperature and then to $0-5{ }^{\circ} \mathrm{C}$. Freshly prepared acryloyl chloride $(0.11$ moles $)$ was added drop wise within 60 minutes to the cooled reaction mixture. The temperature was maintained around $0-5{ }^{\circ} \mathrm{C}$ during the addition. After completion of addition, reaction mixture was stirred for 90 minutes and it was poured into crushed ice water mixture where a light brown color liquid product settled down. It was extracted with ether. The ether layer was separated out and evaporated. The liquid monomer obtained after evaporation of ether was dried over anhydride calcium chloride in vacuum desiccators. The yield was $83 \%$.

IR of 2,4-DCPA $\left(\mathrm{cm}^{-1}\right)$ : 3015(-CH stretching vibration of the aromatic ring), 2978 $\left(v_{-\mathrm{CH} 3}\right), 1756\left(v_{\mathrm{C}=\mathrm{O}}\right)$ [17], 1640( $\left.v_{\mathrm{C}=\mathrm{C}}\right), 1230\left(\right.$ asymmetric $\left.v_{\mathrm{C}-\mathrm{O}-\mathrm{C}}\right)$, 1150 (symmetric $v_{\mathrm{C}-\mathrm{O}-\mathrm{C}}$ ), 890 (- $\mathrm{CH}$ bending mode of vinyl group), 730 (rocking mode of vinyl group), $667(v$, ) [18]. The two absorption bands at 1593 and $1480 \mathrm{~cm}^{-1}$ may be assigned as the characteristic absorption of o-substituted phenyl ring $[19,20]$. Figure 1 (a) shows the IR spectrum of monomer 2,4DCPA, and Figure 1(b) shows ${ }^{1} \mathrm{H}-\mathrm{NMR}$ spectrum of monomer 2,4-DCPA.

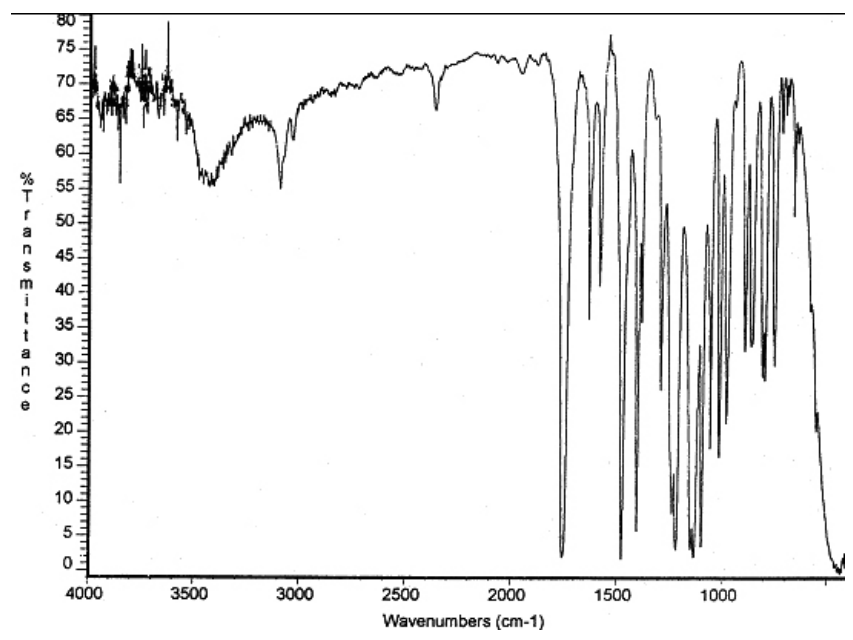

Figure 1(a): FT-IR spectrum of monomer 2,4-DCPA. 


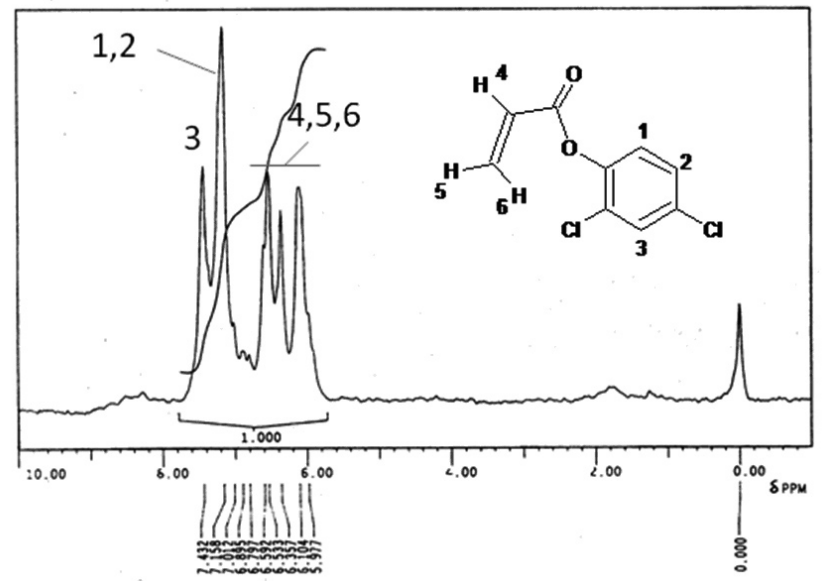

Figure 1(b): ${ }^{1} \mathrm{H}-\mathrm{NMR}$ spectrum of monomer 2,4-DCPA.

Copolymerization:

Copolymers of 2,4-DCPA with MMA having different feed composition were synthesized by free radical polymerization in DMF using AIBN as a free radical initiator. The feed composition of monomer and comonomer are giving in Table I. Appropriate quantities of monomer, comonomer, DMF (10mL) and $\operatorname{AIBN}(0.5 \% \mathrm{w} / \mathrm{w})$ based on total monomers were taken in a polymerization tube equipped with reflux condenser. The reaction mixture was heated at $70^{\circ} \mathrm{C}$ for 5 hrs with stirring. It was then cooled to room temperature and the resulting polymer solution was slowly poured in a large volume of methanol with stirring, where the polymer precipitated out. It was filtered and washed with methanol. Solid polymer were purified by repeated precipitation by methanol from solution in DMF and finally dried. Reaction Scheme (Figure-2) show the step leading to the formation of homopolymer of 2,4-DCPA (Poly(2,4-DCPA)), MMA (Poly(MMA)) and its copolymers (Poly(2,4-DCPA-co-MMA)).

Table I: Copolymer composition and reactivity ratios of copolymers of 2,4- DCPA and MMA.

\begin{tabular}{|c|c|c|c|c|c|c|c|c|c|c|}
\hline $\begin{array}{c}\text { Sample } \\
\text { Code } \\
\text { No. }\end{array}$ & $\begin{array}{c}2,4- \\
\text { DCPA } \\
{\left[M_{1}\right]} \\
\text { Mole }\end{array}$ & $\begin{array}{c}\text { MMA } \\
{\left[\mathbf{M}_{2}\right]} \\
\text { Mole }\end{array}$ & $\begin{array}{c}\% \\
\text { Conversion }\end{array}$ & $\begin{array}{c}\text { Composition of } \\
\mathrm{P}(2,4-\mathrm{DCPA}) \\
\text { in copolymer } \\
{\left[\mathrm{m}_{1}\right]}\end{array}$ & $\mathbf{X}$ & $\mathbf{Y}$ & $\mathbf{F}$ & G & $\xi$ & $\eta$ \\
\hline 2 & 0.2 & 0.8 & 7.65 & 0.267 & 0.25 & 0.364 & 0.172 & -0.437 & 0.137 & -0.347 \\
\hline 3 & 0.4 & 0.6 & 9.18 & 0.458 & 0.67 & 0.845 & 0.531 & -0.123 & 0.328 & -0.076 \\
\hline 4 & 0.5 & 0.5 & 8.20 & 0.542 & 1.0 & 1.183 & 0.845 & 0.155 & 0.437 & 0.080 \\
\hline 5 & 0.6 & 0.4 & 8.68 & 0.584 & 1.5 & 1.404 & 1.603 & 0.432 & 0.596 & 0.161 \\
\hline 6 & 0.8 & 0.2 & 9.20 & 0.730 & 4.0 & 2.704 & 5.917 & 2.521 & 0.845 & 0.360 \\
\hline
\end{tabular}

Where, $\mathrm{m}_{2}=1-\mathrm{m}_{1} ; \mathrm{X}=\mathrm{M}_{1} / \mathrm{M}_{2} ; \mathrm{Y}=\mathrm{m}_{1} / \mathrm{m}_{2} ; \mathrm{F}=\mathrm{X} / \mathrm{Y} ; \mathrm{G}=\mathrm{X}(\mathrm{Y}-1 / \mathrm{Y}) ; \xi=\mathrm{F} / \alpha+\mathrm{F} ; \eta=\mathrm{G} / \alpha+\mathrm{F}$ and $\alpha=\left[\mathrm{F}_{\mathrm{M}} \cdot \mathrm{F}_{\mathrm{m}}\right]^{1 / 2}$

Characterization of polymers:

NICOLET 400D FT-IR Spectrophotometer was used to recorded the spectrum of monomer, homopolymer and copolymer on solid KBr pellets. A Simadzu160 recording UV-Visible spectrophotometer was used to determine copolymer composition and reactivity ratio. KNAUR (Germany) Vapor Pressure Osmometer (VPO) was used to determine the number average molecules weight of homo as well as copolymers. TA instrument (U.S.A)-2960 thermo gravimetric analyzer was used to perform TGA and DTA at a heating rate of $10^{\circ} \mathrm{C} / \mathrm{min}$ in nitrogen atmosphere. 
( a )<smiles>C=CC(=O)Oc1ccc(Cl)cc1Cl</smiles>

2.4-DCPA

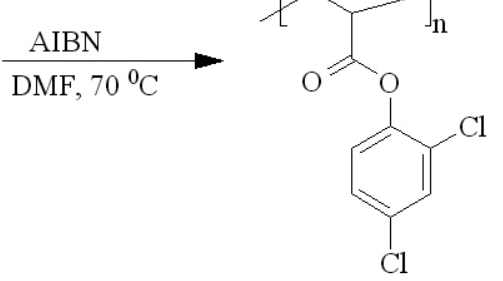

Poly (2,4-DCPA) (b)<smiles>C=CC(=O)Oc1ccc(Cl)cc1Cl</smiles>

2,4-DCPA<smiles>C=C(C)C(=O)OC</smiles>

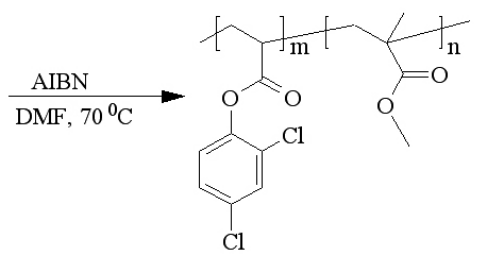

MMA

Poly(2,4-DCPA-co-MMA) (c)<smiles>C=C(C)C(=O)OC</smiles>

$\frac{\mathrm{AIBN}}{\mathrm{DMF}, 70^{\circ} \mathrm{C}}$

MMA

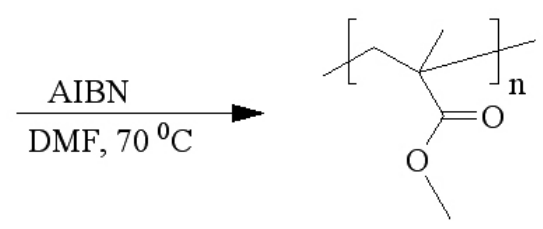

Poly(MMA)
Figure 2: Reaction Scheme Synthesis of (a) poly(2,4-DCPA), (b) poly(2,4DCPA-Co-MMA) (c) poly(MMA).

\section{Antimicrobial Activity:}

The synthesized homo- and copolymers were tested against different a microorganism that's commonly employed for biodegradability tests. Bacterial strains (Bacillus subtilis, Escherichia coil, and Staphylococcus), fungi (Aspergillus niger, Sporotichum pulverulentum, and Trichoderma lignorum), and yeast (Caniada uilis, Saccharomyces cerevisiae, and Pichia stipitis) were grown in Nutrient broth (N-broth) and Subourand's dextrose broth and YEPD (Yeast Extract Peptone Dextrose) media, respectively, with or without indicated polymers.

\section{(a) Bacterial Cultivations}

$5 \%(\mathrm{v} / \mathrm{v})$ inoculums of bacterial culture was used to inoculated $100 \mathrm{~mL}$ $\mathrm{N}$-broth solution [control (without polymer)] and test media (100 mL N-broth + $50 \mathrm{mg}$ polymer) and incubated on rotary shaker $(200 \mathrm{rpm})$ at room temperature. $0.5 \mathrm{~mL}$ liquids were withdrawn at specified time intervals (20-48 h) from test media. After suitable dilution with distilled water, absorbance was measured at $660 \mathrm{~nm}$ and calculated as absorbance per $\mathrm{mL}$ (i.e. growth). The method is based on the principle that as the growth proceeds, cell number increases which leads to increase in absorbance of medium. The percentage inhibition for bacteria was calculated by the following formula:

$$
\text { Percentage inhibition }=\frac{100(\mathrm{X}-\mathrm{Y})}{\mathrm{X}}
$$

Where $\mathrm{X}=$ absorbance of bacterial suspension in control set $\mathrm{Y}=$ absorbance of bacterial suspension in test set.

\section{(b) Fungal Cultivation}

Since fungal culture shows filamentous growth, optical method can not used to monitor the growth, therefore gravimetric analysis was carried out to determine dry cell mass. $10 \%(\mathrm{v} / \mathrm{v})$ inoculum was added to the sterile control medium (without polymer) and test medium $(100 \mathrm{~mL}$ control medium $+50 \mathrm{mg}$ polymer). Flasks were incubated at room temperature on rotary shaker $(200$ rpm) for 40 hours. Content of flasks were filtered using cheesecloth and cell pellets were dried to constant weight. The percentage inhibition for fungi was calculated after 7 days using the following formula:

$$
\text { Percentage inhibition }=\frac{100(X-Y)}{X}
$$

Where $X=$ Weight of dry fungal cell mass in control set $\mathrm{Y}=$ Weight of dry fungal cell mass in test set.

\section{(c) Yeast Cultivation}

$5 \%(\mathrm{v} / \mathrm{v})$ inoculums of yeast culture was added to the $100 \mathrm{~mL}$ of sterile control medium (without polymer) and test medium $(100 \mathrm{~mL}$ control medium + $50 \mathrm{mg}$ polymer) and incubated on rotary shaker $(200 \mathrm{rpm})$ at room temperature. Sample contents were withdrawn at specified time intervals (24 and $48 \mathrm{~h}$ ) from test media. After suitable dilution with distilled water absorbance was measured at $660 \mathrm{~nm}$ and calculated as absorbance per $\mathrm{mL}$ (i.e. growth). The percentage inhibition for yeast was calculated by the following formula:

$$
\text { Percentage inhibition }=\frac{100(\mathrm{X}-\mathrm{Y})}{\mathrm{X}}
$$

Where $X=$ absorbance of yeast suspension in control set $\mathrm{Y}=$ absorbance of yeast suspension in test set.

\section{RESULTS AND DISSUCCION}

The Copolymerization of 2,4-DCPA with MMA in DMF solution was studied in wide composition interval with mole fraction of 2,4-DCPA ranges from 0.2 to 0.8 in the feed. The reaction time was selected to give conversion less then $10 \%$ weight to satisfy the differential copolymerization equation for calculation of reactivity ratio.

The IR-spectra of the copolymers are shown Figure-3. The two bands at $2998 \mathrm{~cm}^{-1}$ and $2956 \mathrm{~cm}^{-1}$ those that appear in all polymers are due to $\mathrm{C}-\mathrm{H}$ stretching mode of alkyl group. The $\mathrm{C}-\mathrm{H}$ stretching vibration of aromatic ring is assigned to a peak around $3022 \mathrm{~cm}^{-1}$. The absorptions at $1390 \mathrm{~cm}^{-1}$ and 1475 $\mathrm{cm}^{-1}$ may be traced to the plane bending vibration of methyl (symmetric methyl bending) and methylene (bending of $\mathrm{CH}_{2}$ ) groups. The compounds show the characteristic strong absorption due to $\mathrm{C}=\mathrm{O}$ stretching of ester groups. In the copolymers two $\mathrm{C}=\mathrm{O}$ stretching vibration are observed at $1765 \mathrm{~cm}^{-1}$ and 1725 $\mathrm{cm}^{-1}$. From a comparison of spectra of (2,4-DCPA) and poly MMA with those $1765 \mathrm{~cm}^{-1}$ peak may be assigned to the $\mathrm{C}=\mathrm{O}$ stretching of the 2,4-DCPA moiety of the copolymers and the $1728 \mathrm{~cm}^{-1}$ peak may be attributed to the same in the MMA moiety. The medium strong absorption in the range $1215-1246 \mathrm{~cm}^{-1}$ may have contribution from $\mathrm{C}-\mathrm{O}-\mathrm{C}$ stretching vibrations of the ester group. The band at $868 \mathrm{~cm}^{-1}$ is due to the $-\mathrm{CH}_{2}$ rocking mode of the methylene chain. The prominent sharp band at $670 \mathrm{~cm}^{-1}$ is attributed to $\mathrm{C}-\mathrm{Cl}$ stretching [21].

The NMR signal at around $7.6 \delta$ (Fig.-1(b)) is due to the aromatic proton No.-3 and the peak of $7.2 \delta$ may be due to the aromatic protons No.- 1 and 2 . The NMR signal due to vinylic protons appears in the 6.0 t0 $6.6 \delta$.

\section{Copolymer Composition and Reactivity Ratio:}

The average composition of each copolymer sample was determined from the corresponding UV-Spectrum. The composition of each monomer in the polymer was obtained from measurement of absorption at $\lambda_{\max }=272$ $\mathrm{nm}$ which is the characteristic $\lambda_{\max }$ for 2,4-DCPA. From monomer feed ratio and copolymer composition, the reactivity ratio of 2,4-DCPA and MMA were determined using F-R method [22] and K-T [23] method (Fig. 4 and Fig. 5 respectively).

\section{Molecular weights and Viscosity Measurement:}

The number average molecular weights of copolymers were determined by VPO using DMF as a solvent at $90^{\circ} \mathrm{C}$. The value of number average molecular weight and intrinsic viscosity various between $5382-7923 \mathrm{~g} / \mathrm{mol}$ and $0.011-$ $0.021 \mathrm{dL} / \mathrm{gm}$ respectively. From these data (Table-2) it is concluded that as the 2,4-DCPA content increases in the copolymer the molecular weight viscosity change randomly (i.e. increases or decreases). 


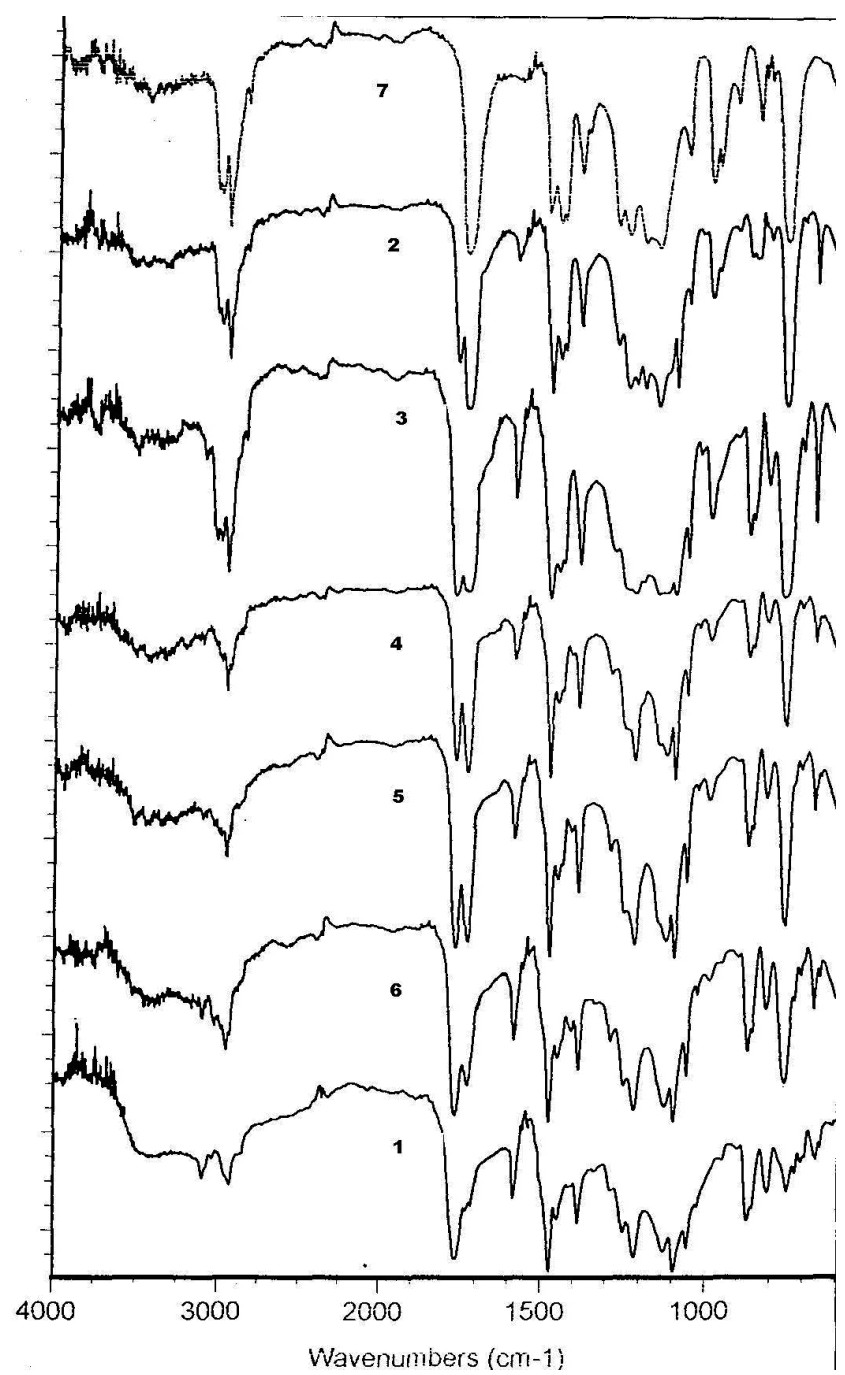

Figure 3: FT-IR spectra of poly(2,4-DCPA) (1), poly(MMA) (7) and poly(2,4-DCPS-co-MMA) (2-6).

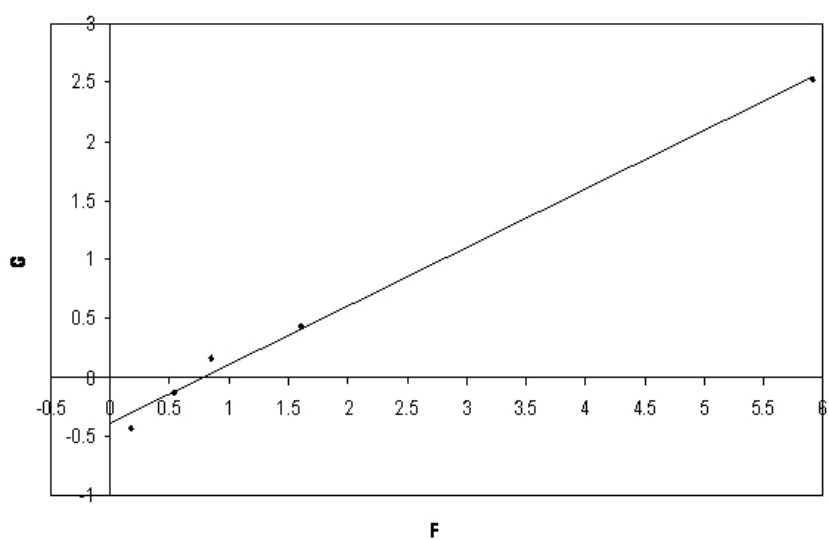

Figure 4: F-R plot for poly(2,4-DCPA-co-MMA).

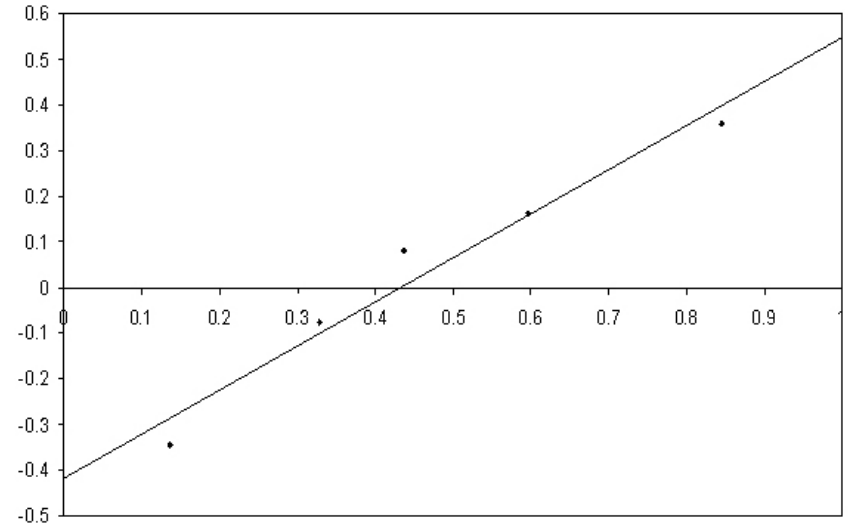

Figure 5: K-T plot for poly(2,4-DCPA-co-MMA).

Table II: VPO and viscosity data for poly(2,4-DCPA), poly(MMA) and poly(2,4-DCPA-co-MMA).

\begin{tabular}{|c|c|c|}
\hline $\begin{array}{c}\text { Sample } \\
\text { Code No. }\end{array}$ & $\begin{array}{c}\text { Mn } \\
\left(\mathbf{g} . \mathbf{m o l}^{-1}\right)\end{array}$ & $\begin{array}{c}\text { Intrinsic } \\
\text { Viscosity } \\
\left.\text { [ๆl (dL. }{ }^{-1}\right)\end{array}$ \\
\hline 1 & 7923 & 0.021 \\
\hline 2 & 5382 & 0.011 \\
\hline 3 & 5781 & 0.012 \\
\hline 4 & 5945 & 0.013 \\
\hline 5 & 6405 & 0.014 \\
\hline 6 & 6800 & 0.016 \\
\hline 7 & 6968 & 0.016 \\
\hline
\end{tabular}

Thermal Analysis:

The data from TGA of homo and copolymers are presented in Table-3. The data clearly indicted that all polymers undergo single step decomposition expect the 2,4-DCPA. Activation energy $\left(\mathrm{E}_{\mathrm{A}}\right)$ and integral procedure decomposition temperature (IPDT) were determined by Broido's method [24] and Doyle's method [25]. Thermal studies showed that the polymers undergo decomposition in the range of $191-440^{\circ} \mathrm{C}$. The activation energy $\left(\mathrm{E}_{\mathrm{A}}\right)$ lies in the range of $61-75 \mathrm{~K} . J . \mathrm{mol}^{-1}$.

The result of DTA of homo and copolymers are shown in Table-4. The activation energy for thermal degradation determine by Reich's method [26] of polymers ranged from $60-76$ K.J.mol ${ }^{-1}$.

\section{Antimicrobial Activity:}

The microbial screening of homo and copolymer of 2,4-DCPA and MMA were investigated. The obtain results are presented in Fig. 6, 7, and 8. All the polymers showed almost similar antimicrobial properties against bacteria, fungi, and yeast. Poly(2,4-DCPA) allows $50 \%$ growth for bacterial poly(MMA) allows $92 \%$ growth for bacterial whereas its copolymer favor $68-86 \%$ growth. Fungi shows $45 \%$ growth for poly(2,4-DCPA), $91 \%$ growth for poly(MMA) and $65-87 \%$ for copolymers. Yeast shows $43 \%$ growth for poly(2,4-DCPA), $75 \%$ growth for poly(MMA) and $57-73 \%$ growth for copolymers.

All copolymers system imparts almost similar antimicrobial properties against bacteria, fungi and yeast. It was observed that polymers prepared using 2,4-DCPA showed strong inhibitory effect towards the microorganisms tested. As the 2,4-DCPA content increases in the copolymer, the effectiveness of the copolymers to inhibit the growth of microorganism increases as expected. 
J. Chil. Chem. Soc., 54, № 3 (2009)

Table III: TGA data for homo- and copolymers of 2,4-DCPA with MMA.

\begin{tabular}{|c|c|c|c|c|c|c|c|c|c|c|}
\hline \multirow{2}{*}{$\begin{array}{l}\text { Sample } \\
\text { Code } \\
\text { No. }\end{array}$} & \multicolumn{5}{|c|}{$\%$ Weight loss at various temperature $\left({ }^{\circ} \mathrm{C}\right)$} & \multirow{2}{*}{$\begin{array}{c}\text { Decomposition } \\
\text { Temperature } \\
\text { Range }\left({ }^{\circ} \mathrm{C}\right)\end{array}$} & \multirow{2}{*}{$\begin{array}{c}\operatorname{Tmax}^{\mathrm{a}} \\
\left({ }^{\circ} \mathrm{C}\right)\end{array}$} & \multirow{2}{*}{$\begin{array}{l}\text { T50 } \\
\left({ }^{\circ} \mathrm{C}\right)\end{array}$} & \multirow{2}{*}{$\begin{array}{c}\text { IPDT }^{\circ} \\
\left({ }^{\circ} \mathrm{C}\right)\end{array}$} & \multirow{2}{*}{$\begin{array}{c}\text { Activation } \\
\text { Energyd (Ea) } \\
\left(\text { K.J.mol }{ }^{-1}\right)\end{array}$} \\
\hline & 200 & 300 & 400 & 500 & 600 & & & & & \\
\hline 1 & 1 & 6 & 79 & 87 & 92 & $\begin{array}{l}191-340 \\
341-424\end{array}$ & 389 & 383 & 403 & 75 \\
\hline 2 & 5 & 11 & 97 & 99 & - & $274-408$ & 358 & 351 & 355 & 68 \\
\hline 3 & 12 & 18 & 92 & 95 & 98 & $214-410$ & 373 & 364 & 385 & 72 \\
\hline 4 & 0 & 1 & 55 & 81 & 85 & $307-440$ & 398 & 396 & 402 & 63 \\
\hline 5 & 2 & 26 & 92 & - & - & $241-417$ & 366 & 351 & 378 & 61 \\
\hline
\end{tabular}

a Temperature for maximum rate of decomposition

${ }^{\mathrm{b}}$ Temperature for $50 \%$ weight loss

${ }^{\mathrm{c}}$ Integral procedural decomposition temperature

'By Broido's method

Table IV: DTA data for homo- and copolymers of 2,4-DCPA with MMA

\begin{tabular}{|c|c|c|c|c|c|}
\hline $\begin{array}{l}\text { Sample } \\
\text { Code } \\
\text { No. }\end{array}$ & $\begin{array}{l}T_{1}{ }^{a} \\
\left({ }^{\circ} \mathrm{C}\right)\end{array}$ & $\begin{array}{l}\mathrm{T}_{2}{ }^{\mathrm{b}} \\
\left({ }^{\circ} \mathbf{C}\right)\end{array}$ & $\begin{array}{l}T_{b}{ }^{c} \\
\left({ }^{\circ} \mathrm{C}\right)\end{array}$ & $\begin{array}{c}\text { Activation } \\
\text { Energy }^{\mathrm{d}}\left(\mathbf{E}_{\mathrm{A}}\right) \\
\left(\text { K.J.mol }^{-1}\right)\end{array}$ & $\begin{array}{c}\text { Reaction } \\
\text { Order }\end{array}$ \\
\hline 1 & 385 & 440 & 412 & 76.44 & 1 \\
\hline 2 & 361 & 482 & 402 & 66.52 & 1 \\
\hline 3 & 380 & 468 & 399 & 69.77 & 1 \\
\hline 4 & 311 & 402 & 351 & 60.81 & 1 \\
\hline 5 & $\begin{array}{l}295 \\
382\end{array}$ & $\begin{array}{l}380 \\
452\end{array}$ & $\begin{array}{l}322 \\
423\end{array}$ & $\begin{array}{l}59.80 \\
28.09\end{array}$ & $\begin{array}{l}1 \\
1\end{array}$ \\
\hline
\end{tabular}

${ }^{\text {a }}$ Starting Temperature of DTA trace

${ }^{\mathrm{b}}$ Ending Temperature of DTA trace

c Peak maxima Temperature of DTA trace

d Activation Energy by Reich's method

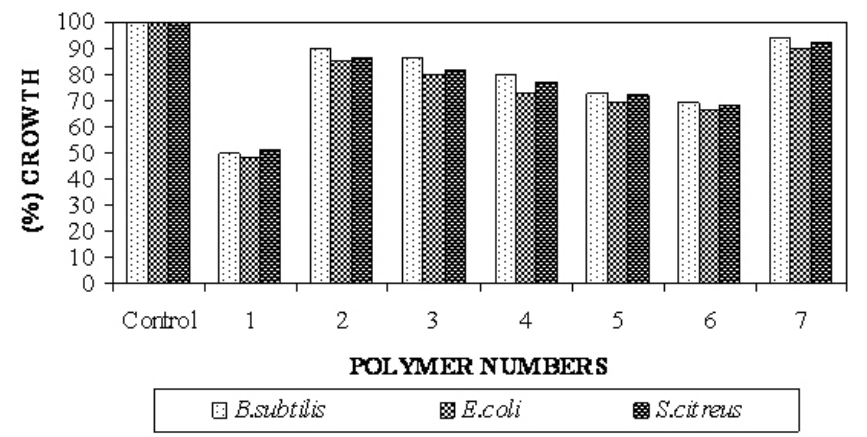

Figure 6: Effect of poly(2,4-DCPA) (1), poly(MMA) (7) and poly(2,4DCPS-co-MMA) (2-6) on growth (\%) of bacteria.

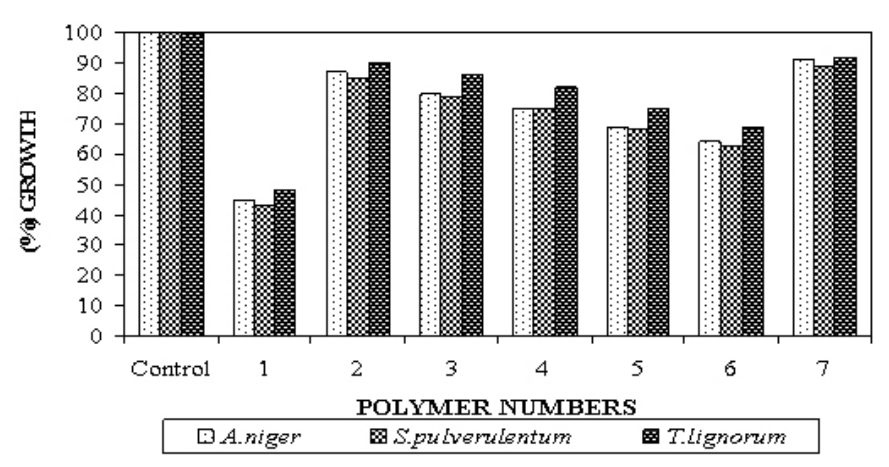

Figure 7: Effect of poly(2,4-DCPA) (1), poly(MMA) (7) and poly(2,4DCPS-co-MMA) (2-6) on growth (\%) of fungi. 


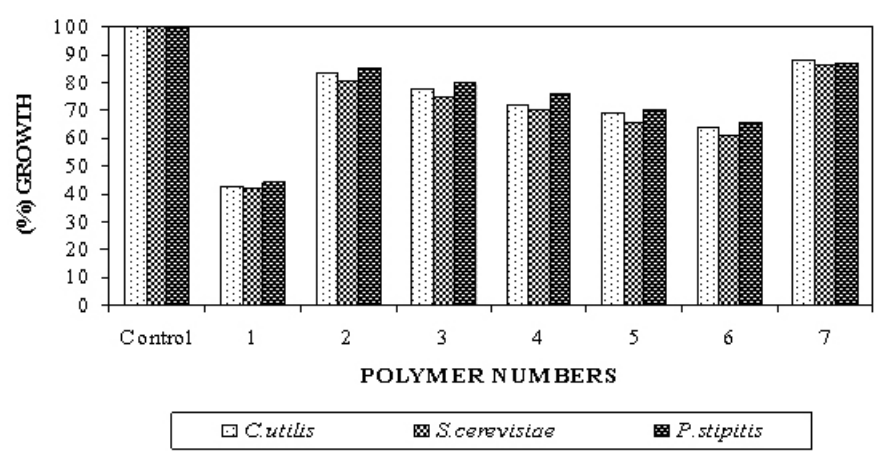

Figure 8: Effect of poly(2,4-DCPA) (1), poly(MMA) (7) and poly(2,4DCPS-co-MMA) (2-6) on growth (\%) of yeast.

\section{CONCLUSION}

The homo and copolymers of 2,4-DCPA and MMA having various composition were synthesized by solution polymerization. The monomer and polymers were characterized by spectroscopic methods. Thermal analysis show that all copolymers of 2,4-DCPA undergo single step decomposition and homo polymers decomposition in a double step. We can observe that polymers containing chlorine exhibit strong antimicrobial activity. In the co-polymers we have found that as the 2,4-DCPA content in polymer increases i.e. the amount of chlorine increases, the polymer inhibits more the growth of the microorganism. 2,4-dichloro phenol (2,4-DP ), a well known biocide [27] has been anchored to a polymer by copolymerizing 2,4-dichloro phenyl acrylate ( 2,4-DCPA ) with other vinyl monomers.

\section{REFERENCES}

1. D. A. Tirrell, M. H. Tirrell, N. M. bikalws, C. G. Overberger and G. Menges, Encyclopedia of Polymers Sciences and Engineering, 4, 192 (1985).

2. T. Narasimhaswamy and BSR Reddy, Ind. J. Chem., 34B, 607 (1995).

3. A. Mishra, TJM Sinha and V. J. Choudhary, J. Appl. Polym. Sci., 527, 68 (1998).

4. S. Agarwal, V. Choudhary and IK Verma, Def. Sci. J., 47, 401 (1997).
5. M. Patnaik, V. Choudary and IK Verma, Euro Polym. J., 28, 1433 (1992).

6. E. Strum, Offen Ger., 2,523,093. See Also Chem Abstr., 84, 150522v (1976).

7. A. Pleurdean, C. Point and CM. Brunean, 11 th Int Conf Org Coat Sci Technol 293-301,(1985), See Also Chem Abstr., 105, 210460n (1985).

8. P. Patel, B. shah, A. Ray and R. M. Patel, J. Polym. Research, 11, 65 (2004).

9. M. B. Patel, D. A. Patel and R. M. Patel, Polym Int., 52(3), 367(2003).

10. I. Erol, J. Polym. Sci. Part A: Polym. Chem., 42(13), 3157 (2004).

11. C. Soykan and I. Erol, J. Polym. Research, 11(1), 53 (2004).

12. A. Bozkurt and B. Karadedeli, Reactive and Functional Group, 67(4), 348 (2007).

13. P. S. Vijayanand, S. Kato, S. Satokawc and T. Kojima, Euro. Polym. J., 43(5), (2007)

14. U. Sentilkumar, K. Ganeshan and BSR Reddy, J. Polym. Res., 10, 21 (2003).

15. U. Sentilkumar, R. Balaji, A. Prasth and S. Nanyudan, J. Macromol. Sci. Pure Appl. Chem., 38(1), 67 (2001) Chem. Abstr., 134(25), 353624d (2001).

16. G. H. Stempel, R. P. Cross and R. P. Mareioll . J. Am. Chem. Soc., 72, 2299 (1950).

17. L. J. Bellamy, Advances in Infrared Group Frequencies, England: Methuen \& Co Ltd., (1968).

18. G. H. Silverstein and F. X. Webster. Spectrometric Identification of Organic Compounds, $6^{\text {th }}$ edition, New York: John Wiley \& Sons Inc., (1998).

19. N. B. Colthup, L. H. Daly and S. E. Wiberley., Introduction to Infrared Spectroscopy, New York: Academic Press, (1990).

20. L. J. Bellamy. The Infrared Spectra of Complex Molecules, London: Champman \& Hall, (1975).

21. R. M. Silverstein,; Webster, F. X. Spectrometric Identification of Oraganic Compounds, $6^{\text {th }}$ edition; John Wiley \& Sons, Inc.: New York, (1998).

22. M. Fineman and S. D. Ross, J. Polym. Sci., 5(2), 259 (1950).

23. T. Kelen and F. Tudos, J. Macro. Sci. Chem., A9, 1 (1975).

24. A. Briodo, J. Polym. Sci., A-2, 7, 1761 (1969).

25. C. D. Doyle,. Anal. Chem., 33, 77 (1961).

26. L. Reich, Die Makromol. Chem., 123, 421 (1969).

27. J. Eric Lien, Corwin Hansch, S. M. Anderson, J Medical Chem., 11(3), 430 (1968) 